\title{
Protecting the karst Te Waikoropupū Springs in New Zealand
}

\author{
Donald J Mead \\ 26 Gibbs Road, Collingwood, 7073, New Zealand; (don.mead@gmail.com)
}

doi: $10.4154 / g c .2018 .08$

Article history:

Manuscript received December 11, 2017

Revised manuscript accepted May 25, 2018

Available online June 21, 2018

\begin{abstract}
The sacred Te Waikoropupū Springs are New Zealand's largest, have some of the clearest freshwater worldwide and are a major tourist attraction. They are part of a large karst system, the Arthur Marble Aquifer complex of $180 \mathrm{~km}^{2}$ that has two main interconnected aquifers which have mean residence times of 10.2 and 1.2 years, respectively. The Springs have a high water clarity of $63 \mathrm{~m}$, due to the action of biofilms and stygofauna in the aquifers; to protect this water clarity it is recommended that the level of $\mathrm{NO}_{3}-\mathrm{N}$ in the Springs should not exceed $0.4 \mathrm{mg} / \mathrm{L}$. In the aquifers' unconfined zone there are $45 \mathrm{~km}^{2}$ of lowland, free-draining gravels that receive over $2000 \mathrm{~mm} / \mathrm{a}$ rainfall. The intensification of dairy farming on these soils has resulted in the Springs $\mathrm{NO}_{3}-\mathrm{N}$ rising to above this trigger concentration of $0.4 \mathrm{mg} / \mathrm{L}$.

Three processes, in order of effectiveness, are being considered to control farm impacts on water quality:

1. Dairy farmers have volunteered to stop cattle having direct access to waterways, to manage their dairy-shed waste better and to plant narrow riparian strips. There is some evidence this has reduced farming impacts to waterways.

2. The second method, promoted by the local regional council, is to have stakeholders, assisted by professionals, to recommend water allocation and water quality guidelines for inclusion in their regional plan. This method is ongoing. However, it could be captured by special interest groups and the rules could be relaxed over time. Consultation with the local indigenous Iwi (tribe), who have strong spiritual values for water, is essential.

3. To afford the strongest protection a local Iwi, Ngāti Tama, and Andrew Yuill have applied for a Water Conservation Order (WCO) on the Springs complex and aquifers. This is allowed for in New Zealand law, would provide the strongest long-term protection and, when granted, has to be implemented by the Council.
\end{abstract}

A very recent, but untested, alternative would be to give the waterbody personhood (legal status equivalent to a human), to be managed by guardians. This has been done for one New Zealand River.

To protect the aquifers, the WCO, which offers the greatest control, is recommended.
2016; JULIAN, et al., 2017) and as WILLIAMS (2004) has stated, karst systems are particularly susceptible to pollution.

This paper looks at the management options to ensure that Te Waikoropupū Springs and associated aquifers are sustainably managed and their high values are conserved. While these options are detailed in a New Zealand context the experience should be more widely applicable.

\section{HYDROGEOLOGICAL AND LAND-USE SETTING}

The geology and hydrology of the recharge area supplying Te Waikoropupū Springs and its main marble aquifer have been described in detail by FORD \& WILLIAMS (1989); WILLIAMS (1977, 2004); MUELLER (1991); STEWART \& THOMAS (2008) and THOMAS \& HARVEY (2013) and is only briefly described here (Figure 1). The area of the Ordovician Arthur Marble is about $180 \mathrm{~km}^{2}$ and has a thickness of 500 to perhaps $1000 \mathrm{~m}$. Shallow permeable Quaternary gravels from a few to $50 \mathrm{~m}$ thickness cover about $90 \mathrm{~km}^{2}$ of the Takaka valley bottom but in the downstream half of the area these gravels are underlain by the impermiable Tertiary Motupipi Coal Measures (increasing from zero in upper the Takaka valley to $305-500 \mathrm{~m}$ close to the sea) which form the main cap of the artesian system (WILLIAMS, 1977; WILLIAMS pers. comm.). Other Tertiary formations include the Tarakohe problem in many parts of New Zealand (SCARSBROOK et al., 
Mudstone (600 $\mathrm{m}$ thick) and the Takaka Limestone (on the Northern and Eastern Side of Takaka Valley and 4 - 62 m thick). These formations overlie the Arthur Marble. The total area of unconfined marble aquifer is $135 \mathrm{~km}^{2}$ of which over $45 \mathrm{~km}^{2}$ is covered by the valley bottom gravels (WILLIAMS, 2004). The Takaka and Waingaro rivers and the unconfined gravels, which are important for the recharge of the AMA, are major contributors of water to the AMA (WILLIAMS, 2004; STEWART \& THOMAS, 2008). Further allogenic recharge areas of about $80 \mathrm{~km}^{2}$ occur on the higher hills above the marble formation (WILLIAMS, 2004; STEWART \& THOMAS, 2008).

STEWART \& THOMAS (2008) have suggested there are two parts to the AMA that supply the springs - a larger 'deep' marble aquifer with a storage volume of $3 \mathrm{~km}^{3}$ and a 'shallow', smaller marble aquifer with $0.4 \mathrm{~km}^{3}$ of water. These aquifers are hydraulically connected but may operate fairly independently. There are two main Springs at Te Waikoropupū. The Main spring (Figure 2) and the small adjacent Dancing Sands Spring, which together have an average flow of $10 \mathrm{~m}^{3} / \mathrm{sec}$, are largely fed by water from the deeper part of the marble aquifer with about a quarter being supplied by the shallow part of the aquifer (STEWART \& THOMAS, 2008). This Main spring has a diameter of $60 \mathrm{~m}$ and has several vents (Figure 2; WILLIAMS, 2007). The Fish Creek Springs are located at about $200 \mathrm{~m}$ to the South East and at $3 \mathrm{~m}$ higher elevation than the Main Spring. They have about a third of the flow rate of the Main spring and three-quarters of their flow is from the 'shallow' aquifer (STEWART \& THOMAS, 2008). Water balance calculations for the AMA complex indicate a total discharge of $\sim 20 \mathrm{~m}^{3} / \mathrm{sec}$, implying there is some discharge into the ocean (WILLIAMS, 2004; STEWART \& THOMAS, 2008). There are about 200 doline depressions in the lowland pastures (Figure 3; THOMAS \& HARVEY, 2013).

Isotope and other measurements of the Springs waters indicate that the mean residence time of water in the 'deep' marble aquifer is 10.2 years, although the peak age of discharge is 3 years and there is a long tail of older water (STEWART \& THOMAS, 2008). The 'shallow' part of the aquifer has a mean residence time of 1.2 years with a peak at 0.9 years. The water in this shallow aquifer system is largely recharged from the upper Takaka River and by valley rainfall. Rainfall is high ranging from 2000 to 3500 $\mathrm{mm} / \mathrm{a}$, but pastures on the stony soils are usually water limited in summer (THOMAS \& HARVEY, 2013).

The high clarity of Te Waikoropupū Springs is due to oxidization of colored organic matter by biofilms and stygofauna as it passes through the aquifers (NGĀTI TAMA KI TE WAIPOUNAMU TRUST \& YUILL, 2017, FENWICK, 2016). As the ecology has not been researched, a precautionary approach is needed to protect this ecosystem.

Pastoral farming with sheep began in the Takaka valley in the latter half of the $19^{\text {th }} \mathrm{C}$ and in the early $20^{\text {th }} \mathrm{C}$ following the felling of the native forest (MEAD, 2015). Dairy farming was initially small scale but by the mid-1970s there were about 2500 cows being milked on the lowland unconfined aquifer. This expanded rapidly in the 1990s with increased irrigation (predominantly after 2007) and use of nitrogen fertilizer and imported supplementary feeds. Dairy cows in the unconfined aquifer zone increased between 2005 and 2014 from 5,500 to 6,700 animals and this was followed by a decline to 6200 cows in 2017 (Tasman District Council (TDC), pers. comm.). There is an informal cap on water allocation in the unconfined area. This was fully allocated by 2012 , and enabled about $45 \%$ of the dairy pastures (1020 ha) to be irrigated.
Dairy cows and beef cattle often lead to high leaching of nitrate-N (SCARSBROOK et al., 2016). Thus nitrate-N in the Main Spring is $0.4 \mathrm{mg} / \mathrm{L}$ compared to $<0.1 \mathrm{mg} / \mathrm{L}$ found in waterways in non-pasture areas (MEAD, 2015). The National Policy Statement on Freshwater Management (NPSFM, 2014) and Australian and New Zealand Environment and Conservation Council (ANZECC, 2000) guidelines currently only cover rivers and lakes and do not have criteria for groundwater. In New Zealand the drinking water must have than nitrate- $\mathrm{N}$ concentration below $11.3 \mathrm{mg} / \mathrm{L}$.

To better define the current nutrient status, Friends of Golden Bay (Inc) have been sampling the Main and Fish Springs weekly since February 2016. This research highlighted that in the Main Spring the median nitrate-N concentration to March 2017 was $0.40 \mathrm{mg} / \mathrm{L}$ but that it increased to $0.44 \mathrm{mg} / \mathrm{L}$ between March 2017 and April 2018. Fish Springs have a slightly lower concentration; they increased over these same periods from 0.36 to $0.40 \mathrm{mg} / \mathrm{L}$. FENWICK (2016) has recommended that they should not be allowed to increase so as to safeguard this groundwater ecosystem.

\section{LEGAL SETTING}

New Zealand's Resource Management Act (RMA) governs land and water management (RICHMOND et al., 2004; ROUSE et al., 2016). The act covers both National and Regional levels and has an overarching aim of sustainability. In the case of freshwater, the Central Government has the NPSFW (2014) that local government must comply with. For the Te Waikoropupū Springs and associated aquifers this is Tasman District Council (TDC). However, currently this policy statement is largely silent on groundwater. The RMA has provision for Water Conservation Orders (WCOs) that give protection almost equivalent to National Parks. There are currently 15 WCOs which cover 13 rivers and two lakes.

Under the RMA, local Government has the responsibility for setting policies and rules. TDC does not currently have comprehensive freshwater policies although some aspects, such as disposal of dairy shed waste and consents to take water for irrigation or other use, are prescribed.

The RMA prescribes that, because of the Treaty of Waitangi, Māori values should be considered and be included in decision making (TIPA et al., 2016). Thus the NPSFM (2014) includes Māori values, while there is joint management by local Iwi (tribes), TDC and the Department of Conservation for Te Waikoropupu Reserve but not the associated aquifers. In their 2013 Treaty of Waitangi settlement, it was acknowledged that Ngāti Tama had a close connection to Te Waikoropupū Springs and the Takaka River and its tributaries (NGĀTI TAMA KI TE WAIPOUNAMU TRUST \& YUILL, 2017). With respect to the Springs and AMA, Ngāti Tama Iwi have a song for formal occassions that talks about the bubbling waters that are the tears of spirit ancestors and are vital for their people's health. They believe that Huriawa, the guardian spirit of the Springs, lives in the underground caves and streams. To them the waters are a link between the past and present. For this reason they state the water is sacred, needs to be protected for future generations and must not be polluted.

Both local and central Government have made use of freshwater stakeholder advisory groups, advised by experts, to give guidance to elected officials (ROUSE et al., 2016). This advice is not binding. Currently the Takaka Freshwater and Land Advisory Group (TFLAG) are considering policies and rules that could affect Te Waikoropupū Springs and its aquifers. 


\section{PROTECTION OPTIONS}

There are four options that are or could be employed to help protect Te Waikoropupū Springs and the associated aquifers. These are:

1. Voluntary freshwater plans

2. Regional freshwater plans

3. National freshwater plans including a WCO

4. Legal personhood for the Springs and aquifers

The first three are overlapping. The fourth option is new and untested but is briefly discussed. The evaluation of the various options was made on the basis of New Zealand experiences (Table 1).

\section{DISCUSSION}

In 2003 the dairy industry set up the Dairying and Clean Stream Accord; this was replaced in 2013 by the Sustainable Dairying Water Accord (HOLLAND, 2014). These voluntary plans have made substantial progress on excluding dairy cattle from larger waterways (sometimes with riparian planting), improved dairy shed waste management and more recently helped with farm nutrient management plans. For farmers in the unconfined area of the AMA these efforts, along with less dairy intensification, might partly explain the levelling off of nitrate-N concentrations in Te Waikoropupū Springs since 2013.

Farmers prefer voluntary agreements as they see this as being less costly and bureaucratic (Table 1). However, the limitations are that standards or measures may be weak and some farmers will ignore them. Just fencing off large streams, for example, does not address nitrate leaching in many situations or possible impacts of further intensification. HOLLAND (2014) criticized these dairy accords as they did not measure outcomes in terms of water quality, used voluntary recording and did not include all stakeholders.

Local government in New Zealand has legally enforceable management plans. The TDC plan has or is developing new policies for freshwater, including aquifers. The TDC current plan includes requirements about waste disposal and water allocation but still has to deal with diffuse pollution. Water allocation in the unconfined AMA recharge zone has only had an interim maximum allocation. The TFLAG consultation process was set up to address such issues.
The use of stakeholder advisory groups is frequently recommended as a means to facilitate decision making that reflects community wishes, including for groundwater (FOSTER \& VAN DER GUN, 2016; ROUSE et al., 2016). There can be pitfalls if powerful vested interest groups or politics subvert the process. Several interest groups have left the nationally based New Zealand's Land and Water Forum process as the Government did not follow key recommendations.

ROUSE et al. (2016) have argued that science advisors to stakeholder groups should act as technical 'honest brokers', although they noted it is doubtful that that they can be truly independent. This came to the fore within TFLAG. During TFLAG's process the TDC experts recommended allowing more irrigation in the unconfined part of the aquifer; they also were part of an expert panel sponsored by DairyNZ to set water quality limits for the Springs' water. Their recommendation was to increase the water allocation from the current informal cap of 500 to over 800 $\mathrm{L} / \mathrm{sec}$ apparently to satisfy the needs of dairy farmers on the waiting list and to allow for any further expansion. To justify this, the scientists argued that it would not affect the ecology of the rivers. However, they did not consider possible impacts of greater farm intensification on the underground aquifers. When this proposal was shared with the wider public, the public came out solidly against further water allocation.

Thus for a high-conservation-value karst waterbody, such as the AMA, using only the regional government approach has some dangers (Table 1). Further, controls could be relatively easily weakened over time.

Nationwide rules, such as the NPSFM (2014), do have a direct bearing on the rivers in the Takaka catchment but currently this policy statement does not have mandated rules for groundwater. The overarching policy is to maintain or improve water quality, which implies that nitrate-N should not be allowed to increase further in the AMA and the Springs.

The Ngāti Tama Ki Te Waipounamu Trust and Andrew Yuill applied for a WCO for Te Waikoropupū Springs and associated aquifers in June 2013 and the Minister of Conservation accepted the application in May 2017. The high evidence requirement to show that a WDO is essential often makes this process slow. As mentioned above, Ngāti Tama consider the Springs and the aquifer that supply them as a sacred treasure that deserves the highest protection; they have a spiritual connection with the waters.

Table 1. Options for freshwater management in New Zealand with examples given in italics.

\begin{tabular}{llll}
\hline Option & Organisational Basis & Advantages & Limitations \\
\hline $\begin{array}{l}\text { Voluntary Freshwater } \\
\text { Plans }\end{array}$ & $\begin{array}{l}\text { Voluntary agreements } \\
\text { Best management practice } \\
\text { (Dairy Accords in NZ) }\end{array}$ & $\begin{array}{l}\text { Fewer governmental controls } \\
\text { Reduced compliance costs }\end{array}$ & $\begin{array}{l}\text { Weak control of offenders } \\
\text { Often minimal standards }\end{array}$ \\
\hline $\begin{array}{l}\text { Regional Freshwater } \\
\text { Plans }\end{array}$ & $\begin{array}{l}\text { Policies and rules at the regional level } \\
\text { May employ stakeholder advisors } \\
\text { (Tasman District Council and Takaka Freshwater and } \\
\text { Land Advisory Group) }\end{array}$ & $\begin{array}{l}\text { Potentially controls both water use and } \\
\text { quality }\end{array}$ & $\begin{array}{l}\text { Slow implementation, weak compliance and } \\
\text { potential gradual erosion of standards. }\end{array}$ \\
& $\begin{array}{l}\text { Stakeholder advisory groups helps public } \\
\text { buy-in }\end{array}$ & Subject to lobby group capture \\
\hline $\begin{array}{l}\text { National Freshwater } \\
\text { Plans }\end{array}$ & $\begin{array}{l}\text { Resource Management Plan } \\
\text { National Freshwater Policy Statement }\end{array}$ & $\begin{array}{l}\text { Potentially gives uniformity and integration } \\
\text { with government objectives }\end{array}$ & Subject to politics
\end{tabular}




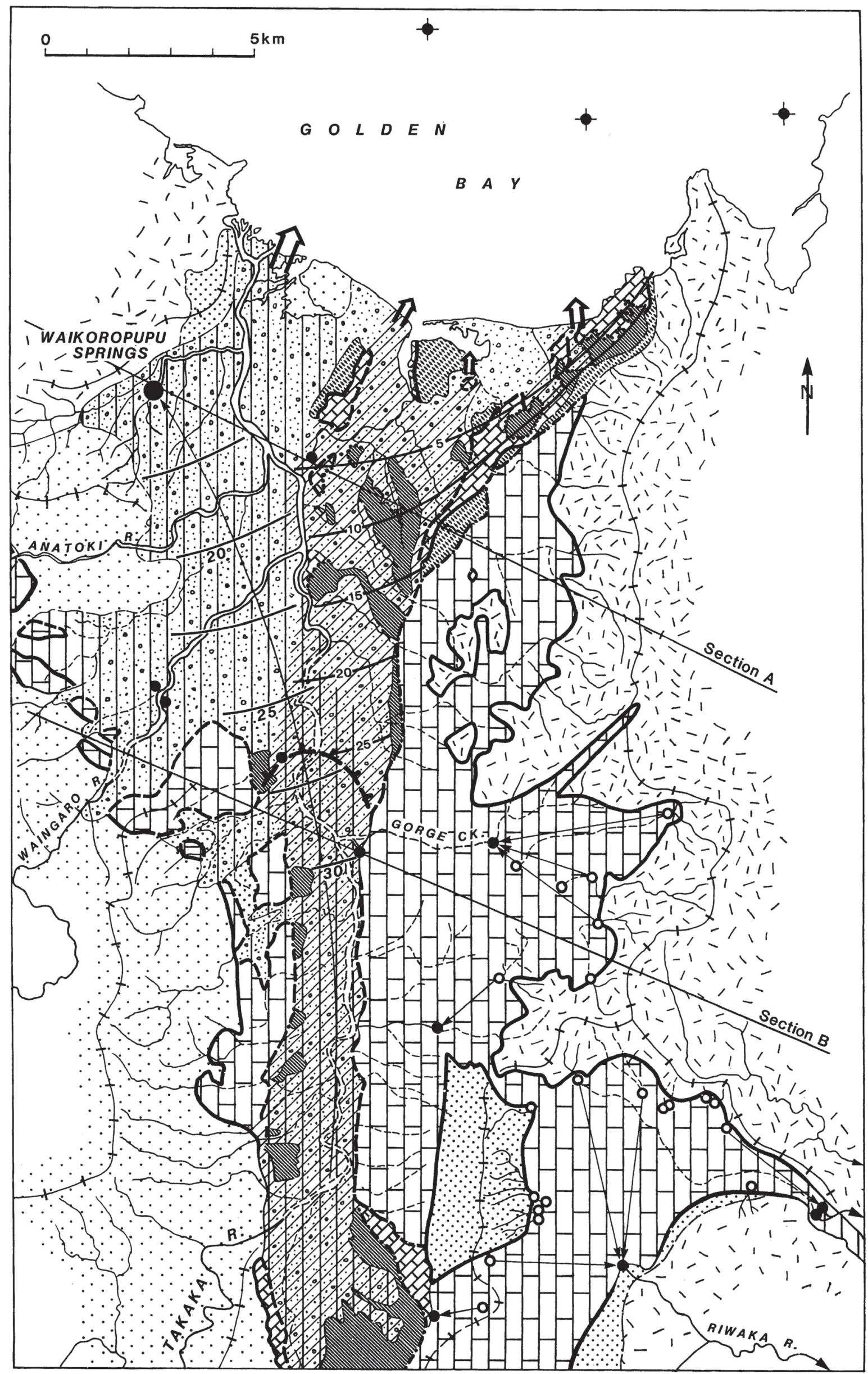

Figure 1. A hydrogeologic map and cross-section of the Takaka Valley (from FORD \& WILLIAMS, 1989). 

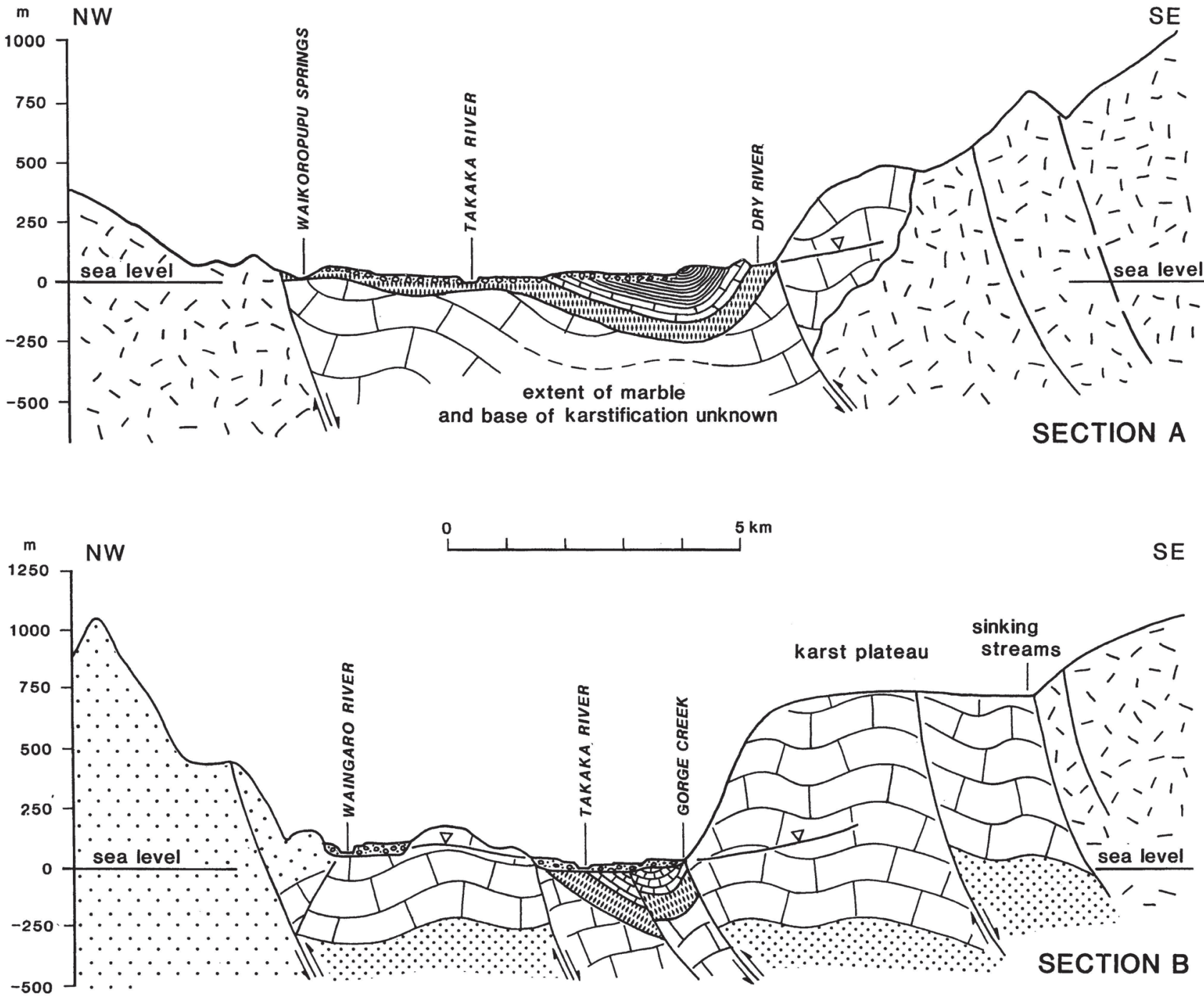

INFLOW BOUNDARY

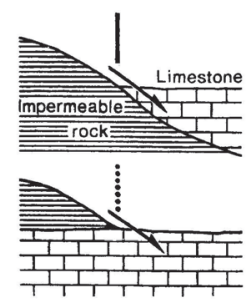

REVERSIBLE FLUX
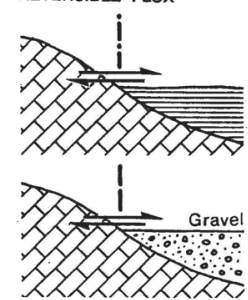

OUTFLOW BOUNDARY

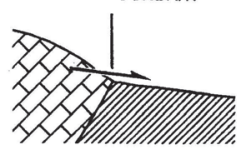

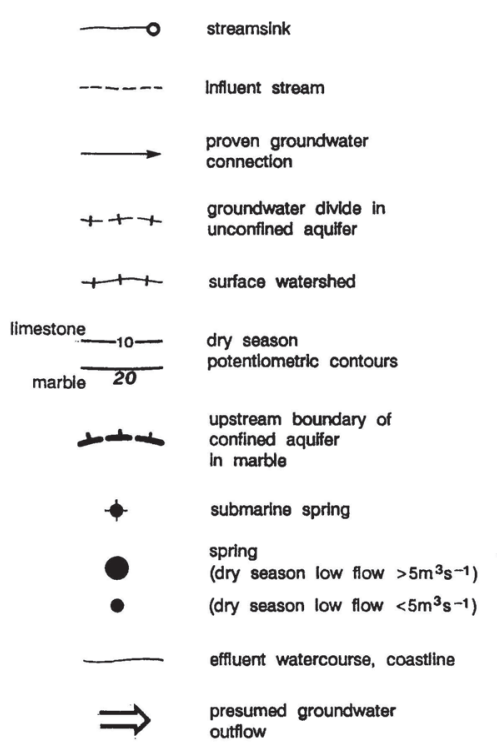

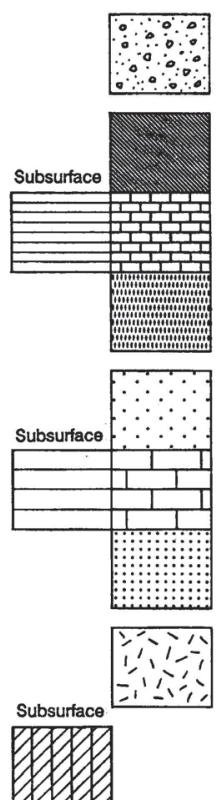

ROCK TYPE AND AGE

Quaternary

sands \& gravels

Miocene

Tarakohe Mudstone

$\sim 600 \mathrm{~m}$

Oligocen

Takaka Limestone
$25-62 \mathrm{~m}$

Eocene

Motupipl Coal Measures

$\sim 5 \cdot 330 \mathrm{~m}$

Ordovician
Onekaka Schist

Ordovician

Arthur Marble
$\sim 1000 \mathrm{~m}$

Ordoviclan

Piklkiruna Schist

Lower Cretaceous to Devonian

Limestone overlying marble sinking

streams $1,->$ . 
In their application they have recommended clear water quality guidelines to protect the groundwater ecosystems of this karst system. These cover:

- water abstraction, with no reduction in flow from the Springs;

- pollution by land use practices, including;

- excessive biological oxygen demand;

- toxins;

- nitrates;

- and effects on $\mathrm{pH}$.

In practice this means sinkholes and streamsides would be off-limits, management practices must avoid affecting the ground- water, while new land-use proposals need to show they will not affect aquifer water quality. The TDC management plan would provide the legal governance, including monitoring and penalties for non-compliance.

A WCO is a National process under the RMA (RICHMOND, et al., 2004). An application to the Minister of the Environment requires that he sets up a tribunal to advise him on the application. Once the WCO is accepted the agreed policies and rules become binding on the Regional Council. The Minister was positive when accepting the WCO application for Te Waikoropupu Springs and aquifers and TFLAG has publically welcomed it. A major advantage of the WCO is that it will be more difficult to alter and proposed changes would have to be publically notified

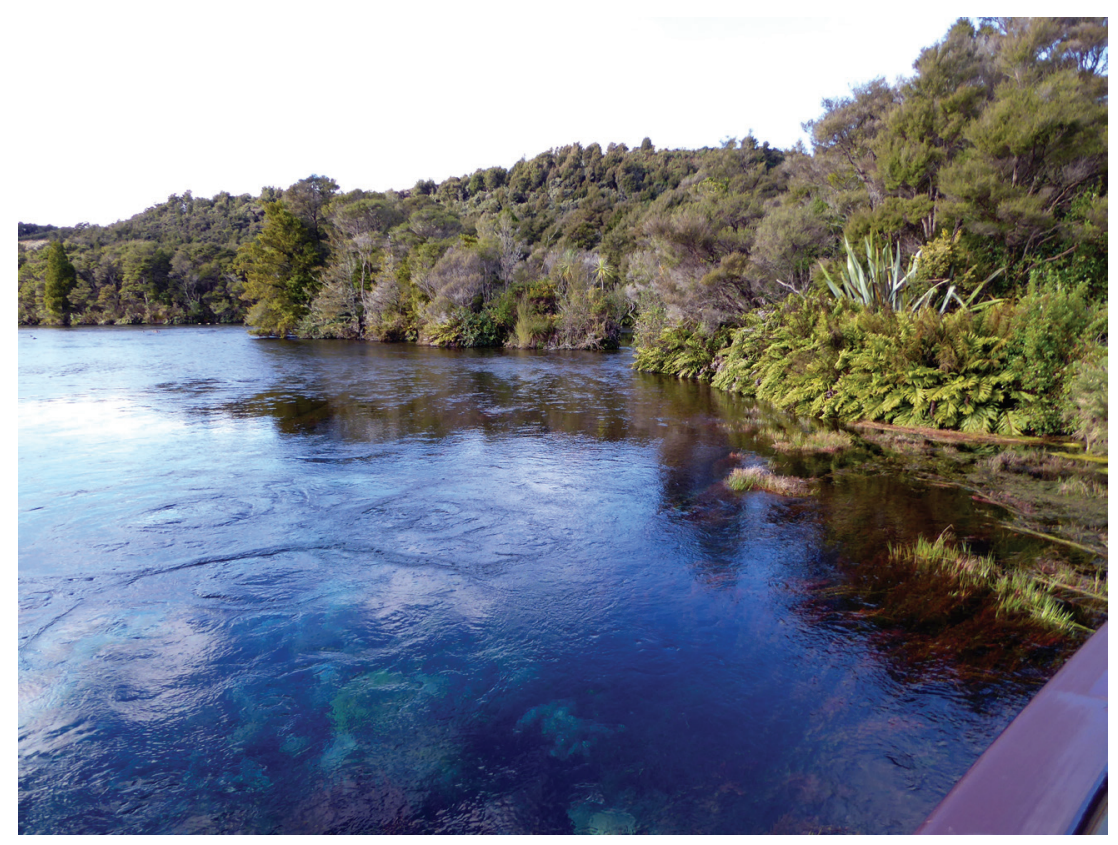

Figure 2. The Waikoropupū Main Spring (photo by D.J. Mead).

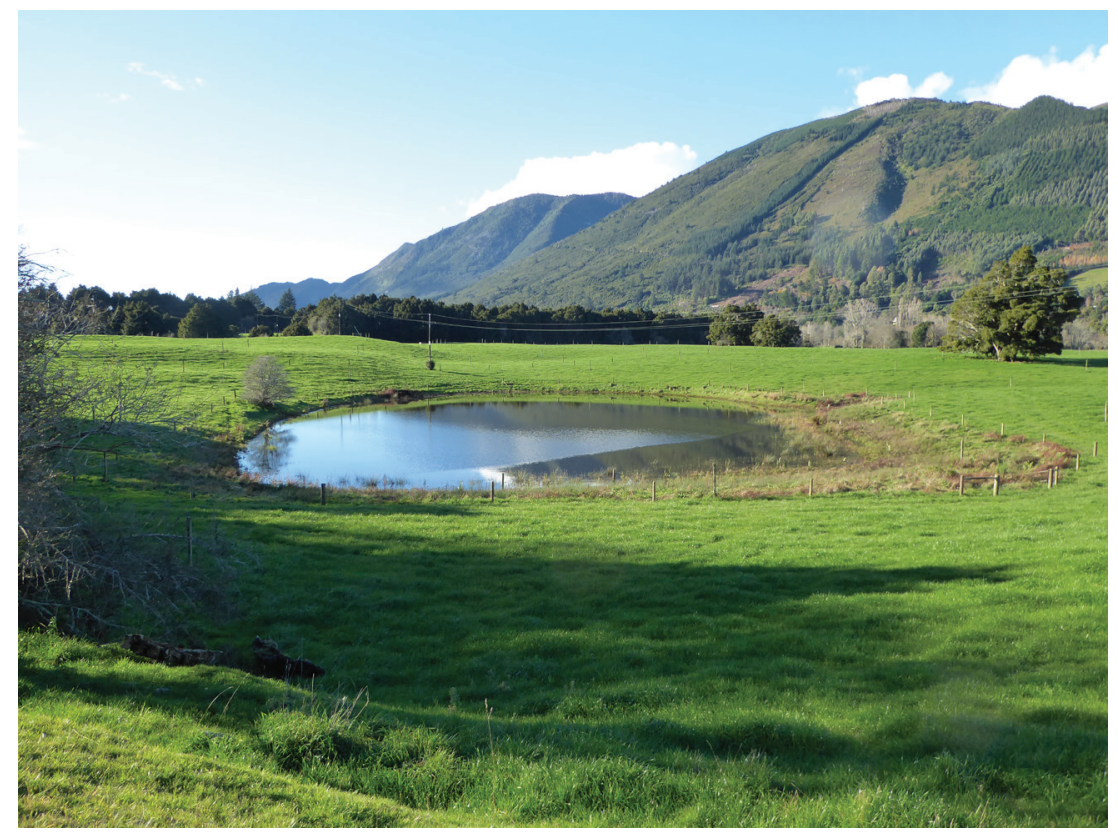

Figure 3. Doline in the Takaka Valley bottom-land pasture (photo by D.J. Mead). 
(Table 1). A disadvantage is that it can sometimes be a long and costly process (RICHMOND et al., 2004).

In March 2017 the New Zealand Government passed an Act to give the Whanganui River legal personhood as part of its Treaty of Waitangi settlement to local Iwi (NEW ZEALAND GOVERNMENT, 2017). This Act recognized that the tribes regarded the river as inseparable from them - 'I am the river and the river is me'. The river is represented by two guardians, one appointed by the Iwi and the other by the Government. The guardians are advised by consultative groups who also must ensure the river's health. As this is the first waterbody worldwide to be given the legal status of a person it is too early to know how well this solution will protect the river (Table 1). However, it clearly fits the Māori worldview that they are inextricably connected with the river and the land.

\section{CONCLUSIONS}

The very high conservation and Iwi values of Te Waikoropupu Springs, coupled with the ongoing pressure for further farming development in the area, makes the use of a WCO the most appropriate mechanism for protecting this waterbody. It is equivalent to giving it National Park status while acknowledging that farming has already modified the landscape. Part of the advantage of the WCO is that it can be supported by other processes including farmer-led voluntary agreements and local body and nationwide instruments.

A WCO is less likely to be captured by vested interests and would be more difficult to change once implemented. In this particular example it has been proposed that there would be no further water abstraction or discharge of contaminants that would cause the proposed limits in the WCO to be exceeded.

Relying solely on voluntary accords or on regional plans, even where these are assisted by stakeholder groups, may not provide the same degree of long-term protection for an outstanding waterbody. Stakeholder groups are usually advisory and their recommendations can be overruled at a later stage in the process. There is a danger that technical advisors to advisory groups might not act independently or may overlook some essential attribute. There would be some protection if plans are developed openly and wide debate within society is encouraged (FOSTER \& VAN DER GUN, 2016).

Giving Te Waikoropupū Springs legal personhood status might also have been acceptable to the local Iwi, although this was not part of their Treaty of Waitangi settlement. However, this option is untested while WCO's have been used to protect rivers and lakes for many years in New Zealand.

Currently, a WCO is the best option to protect Te Waikoropupū Springs and associated aquifers; it is supported by the local community.

\section{ACKNOWLEDGEMENT}

The author thanks Andrew YUILL and Paul WILLIAMS for their help in the paper's preparation. Thanks are also due to the two anonymous referees.

\section{REFERENCES}

ANZECC (2000): Australian and New Zealand Guidelines for Fresh and Marine Water Quality. Vol. 1 and 2. Australian and New Zealand Environment and Conservation Council and Agriculture and Resource Management Council of Australia and New Zealand: Canberra.

DAVIES-COLLEY, R.J. \& SMITH, D.G. (1995): Optically pure waters in Waikoropupū ('Pupu') Springs, Nelson, New Zealand.- N. Z. J. Marine and Freshwater Res., 29, 251-256.

FENWICK, G. (2016): Groundwater ecosystems.- In: JELLYMAN, P.G., DAVIE, T.J.A., PEARSON, C.P. \& HARDING, J.S. (eds.): Advances in New Zealand Freshwater Science. N.Z. Freshwater Sci. Soc. \& N.Z. Hydrol. Soc., 345-355.

FORD, D.C. \& WILLIAMS, P.W. (1989): Karst Geomorphology and Hydrology.Chapman \& Hall, London.

FOSTER, S. \& VAN DER GUN, J. (2016): Groundwater governance: key challenges in applying the Global Framework for Action.- Hydrogeol. J., 24, 744-752.

HOLLAND, P. (2014): The dirty dairying campaign and the clean streams accord.- Lincoln Planning Rev., 6, 63-69.

JULIAN, J.P., DE BREUES, K.M., OWSLEY, B., DAVIES-COLLEY, R.J. \& AUSSELL, A.E. (2017): River water quality changes in New Zealand over 26 years: response to land use intensity.- Hydrol. Earth Syst. Sci., 21, 1149-1171.

MEAD, D.J. (2015): Land Use and Water Quality in Te Waikoropupu Springs. PowerPoint presentation to TAKAKA Fresh Water and Land Advisory Group, Tasman District Council on 22 May 2015. Also available at https://www.researchgate.net/ publication/283939463_Land_use_and_water_quality_in_Te_Waikoropupu_ springs

MUELLER, M. (1991): Karst hydrogeology of the Takaka valley, Golden Bay, Northwest Nelson.- N. Z. J. Geol. and Geophys., 34, 11-16.

NGĀTI TAMA KI TE WAIPOUNAMU TRUST \& YUILL, A. (2017): Application for a Water Conservation Order in respect of Te Waikoropupu springs and associated water bodies (including the aquifers, Takaka River and tributaries). Available at: http:/www.mfe.govt.nz/fresh-water/what-government-doing/water-conservation-orders

NEW ZEALAND GOVERNMENT (2017): Te Awa Tupua (Whanganui River Claims Settlement) Bill. 89 p. Available at: http://www.legislation.govt.nz/bill/government/2016/0129/latest/whole.html\#DLM6830851

NPSFWM (2014): National Policy Statement for Freshwater Management 2014 (amended 2017). New Zealand Government. 47 p. Available at: http://www.mfe.govt.nz/ node $/ 23603$

RICHMOND, C., FROUDE, V., FENEMOR, A. \& ZUUR, B. (2004): Management and conservation of natural waters.- In: HARDING, J., MOSLEY, P., PEARSON, C. \& SORRELL, B. (eds): Freshwaters of New Zealand.- N.Z. Hydrol. Soc. \& N.Z. Liminol. Soc., 44.1-44.19.

ROUSE, H.L., NORTON, N., SINNER, J. \& VATTALA, D. (2016): Water policy and planning.- In: JELLYMAN, P.G., DAVIE, T.J.A., PEARSON, C.P. \& HARDING, J.S. (eds.): Advances in New Zealand Freshwater Science.- N.Z. Freshwater Sci. Soc. \& N.Z. Hydrol. Soc., 663-684.

SCARSBROOK, M., MCINTOSH, A., WILCOX, B. \& MATTHAEI, C. (2016): Effects of agriculture on water quality.- In: JELLYMAN, P.G., DAVIE, T.J.A., PEARSON, C.P., HARDING, J.S. (eds.): Advances in New Zealand Freshwater Science. N.Z. Freshwater Sci. Soc. \& N.Z. Hydrol. Soc., 483-503.

STEWART, M.K. \& THOMAS, J.T. (2008) A conceptual model of flow to the Waikoropupū Springs, NW Nelson, New Zealand, based on hydrometric and tracer $\left({ }^{18} \mathrm{O}, \mathrm{Cl},{ }^{3} \mathrm{H}\right.$ and $\left.\mathrm{CFC}\right)$ evidence.- Hydrol. Earth Syst. Sci., 12, 1-19.

THOMAS, J.T. \& HARVEY, M.M. (2013): Water resources of the Takaka water management area.- Tasman District Council, $38 \mathrm{p}$.

TIPA, G., HARMSWORTH, G.R., WILLIAMS, E. \& KITSON, J.C. (2016): Integrating mātauranga Māori into freshwater management, planning and decision-making.- In: JELLYMAN, P.G., DAVIE, T.J.A., PEARSON, C.P. \& HARDING, J.S. (eds.): Advances in New Zealand Freshwater Science. N.Z. Freshwater Sci. Soc. \& N.Z. Hydrol. Soc., 613-637.

WILLIAMS, P.W. (1977): Hydrology of the Waikoropupu Springs: a major tidal karst resurgence in northwest Nelson (New Zealand).- J. Hydrol. (Netherlands), 35, 73-92.

WILLIAMS, P. (2004): Karst systems.- In: HARDING, J., MOSLEY, P., PEARSON, C. \& SORRELL, B. (eds.): Freshwaters of New Zealand. N.Z. Hydrol. Soc. \& N.Z. Liminol. Soc., 31.1-31.20. 